\title{
UNIVERSITYOF
}

FORWARD

THINKING

WESTMINSTER用

WestminsterResearch

http://www.westminster.ac.uk/westminsterresearch

\section{Event satisfaction and behavioural intentions: examining the impact of the London 2012 Olympic Games on participation in sport}

Smith, A., Brown, G. and Assaker, G.

This is an Accepted Manuscript of an article published by Taylor \& Francis in European Sport Management Quarterly, doi: 10.1080/16184742.2017.129419.

The final definitive version is available online:

https://dx.doi.org/10.1080/16184742.2017.1294193

(C) 2017 Taylor \& Francis

The WestminsterResearch online digital archive at the University of Westminster aims to make the research output of the University available to a wider audience. Copyright and Moral Rights remain with the authors and/or copyright owners.

Whilst further distribution of specific materials from within this archive is forbidden, you may freely distribute the URL of WestminsterResearch: ((http://westminsterresearch.wmin.ac.uk/)).

In case of abuse or copyright appearing without permission e-mail repository@westminster.ac.uk 
Event satisfaction and behavioural intentions: examining the impact of the London 2012

Olympic Games on participation in sport.

\begin{abstract}
Research question: Does event satisfaction influence future intentions to attend events and participate in sport? The research addressed this question by focusing on participation in swimming and the influence of watching the London 2012 Olympic Games; an event which sought to create a legacy of mass sport participation.
\end{abstract}

Research methods: Surveys were conducted at the Olympic Aquatics Centre $(n=185)$ and at a Leisure Centre in Plymouth in south-west England $(n=135)$ making it possible to test for differences between people who experienced the London Olympic Games as a live event and those who watched the event on television. Exploratory factor analysis and partial least squares structural equation modelling were used to analyse the data.

Results and Findings: Although there was a positive relationship between event satisfaction and intention to watch swimming events in the future (as a spectator and on television), this was not true for event satisfaction and intention to participate in swimming.

Implications: The findings are consistent with previous studies which suggest that megaevents are unlikely to create sport participation legacies. However, longitudinal studies are needed to test for behavioural changes and to identify the significance of factors associated with access to sport facilities.

\title{
Keywords:
}

Olympic Games, Event satisfaction, Sport participation 


\section{Introduction}

The London 2012 Olympic Games sought to inspire a generation and were "the first Olympics to explicitly promise a legacy in mass sport participation" (Boardley, 2013, p.252). During the build-up to the Games, sports development became a cornerstone of government policies (Parent, 2008) although critical commentary pointed to a strategy vacuum about how to harness the Games to stimulate demand for sport (Weed, Coren, Fiore, Wellard, Chatziefstathiou, Mansfield \& Dowse, 2015). The 2012 Games were expected to inspire people to play more sport via what has been referred to as a 'trickle down or demonstration effect' (Hindson, Gidlow \& Peebles, 1994; Hogan and Norton, 2000). Event-related stimuli have the potential to influence people in different ways and "viewing the event via some form of electronic media - will likely offer a very different experience and be interpreted differently from being physically present at the event" (Silk, 2011, p. 734). Thus, there is a need for research which compares the "inspiration effect reported by spectators at such events" with that of "audiences who follow live sport away from the actual venue (i.e. on television)" (Ramchandani \& Coleman, 2012, p. 269). This is reaffirmed by Smith's (2012) observation that "more research is needed on how these different types of engagement influence the social outcomes of event projects - in particular how they affect the likelihood of a demonstration effect" (p.142).

The study described in this paper responded to these calls for research by examining the relationship between event satisfaction and behavioural intentions among people who attended an Olympic event and those who watched the event on television. The main aim $\underline{\text { was to establish whether event satisfaction influences future intentions to attend events and }}$ participate in sport. We were particularly interested in whether these relationships differed 
between television viewers and live spectators. A survey was administered to spectators at the Aquatics Centre during the 2012 Olympic Games and people who watched the swimming events on television. This allowed researchers to establish levels of participation in swimming and event-related behaviour for both samples and to determine whether event satisfaction affected intentions to participate in swimming and to watch swimming events in the future. By examining different types of viewing experience and their effects on future intentions, the study examined "the consequences of event satisfaction as a developmental force” (Funk, Jordan, Ridinger \& Kaplanidou, 2011, p. 255).

\section{The London 2012 Olympic Games}

The requirement in the Olympic Charter for the International Olympic Committee (IOC) to encourage sport for all (Girginov \& Hills, 2008) is partly a response to the well-documented improvements in health that accompany increases in physical activity (Derom, Van Wynsberghe \& Sceerder, 2015; Funk et al., 2011; World Health Organisation, 2015). It is not surprising that sports development aspirations were part of London's bid to host the 2012 Games (Bullough, 2012) but the degree of emphasis placed on this objective is noteworthy. Following the success of the bid, the Labour government wanted to use the Games to make the UK a world-leading sporting nation (Devine, 2013). Sport England accepted responsibility for delivering one million more active citizens (Weed et al., 2015) and the three main objectives of this agency's strategy ('Grow', 'Sustain' and 'Excel') were designed to achieve this outcome (Bullough, 2012). The development of the Active People Survey (APS) was a response to the need for more accurate and consistent data on participation rates in order to monitor changes and the first annual interviews for the APS were conducted in 2005 (Bullough, 2012). It was suggested that the size and comprehensive nature of the surveys 
made the APS a "catalyst for transforming evidence-based sport policy" (Rowe, 2009, p. 89 cited in Carmichael, Grix \& Marques, 2013).

London 2012 legacy planning was affected by political shifts in the pre-event period, most notably the transition at national level from the Labour government (1997-2010) to one led by the Conservative party. In a detailed critique of policy initiatives prior to the Games, Devine (2013) traces a philosophical change from Labour's 'sport for sport's sake' stance to a more competitive orientation which was adopted by the Conservative - Liberal coalition when it gained power in 2010. A number of changes were introduced including the cancellation of the $£ 140$ million programme which offered free swimming for children aged under 16 and adults aged over 60 at local authority pools. This was accompanied by plans to establish an Olympic and Paralympic-style sports competition in schools across the country with the Secretary of State for Education announcing that "I want competitive sport to be at the centre of a truly rounded education that all schools offer" (Gove, 2010 cited in Devine, 2013, p. 260). Devine (2013) regards the cancellation of the free swimming programme as an interesting indicator of the change in policy direction as the initiative had been an important part of the Labour government's "plans to secure a long-term legacy from London hosting the Olympic and Paralympic Games - and to get two million people more active and more healthy" (Devine, 2013, p. 272). The decision to cancel the However the cancelation of the programme was also prompted by its disappointing effects on the participation rates of people who were not already regular swimmers (PWC, 2010).

The promotion of swimming prior to the Games was not limited to government initiatives. A $£ 15$ million sponsorship of British Swimming by British Gas involved a 50:50 funding split between elite athletes and grassroots activities (Quilter, 2012). It included an advertising campaign which presented Team GB swimmers as superheroes (Pocket-lint, 2012) and an explicit link was made between the Olympics and participation in swimming. People who 
offered support for the British swim team on the British Gas website qualified for 'swim for free' vouchers and opportunities to attend aquatic classes at 700 leisure centres, health clubs and hotels across Britain (Chapman, 2012). At this time, the APS revealed that swimming was the most popular sport in the UK with just under 5 million people participating in the sport each month (Pappous \& Hayday, 2015). The focus on swimming is important in the context of this study because research with similar objectives recommended that "future studies might benefit from assessing the extent to which the Olympic Games motivate specific activity choices" (Potwarka, 2015, p. 90). The study by Potwarka (2015) of students at two universities in Canada, had measured the influence of the 2010 Winter Olympics on intentions to increase general levels of physical activity.

\section{Events and sport participation}

Mass participation sport events, such as running and cycling events, motivate people to become more physically active (Bauman, Murphy \& Lane, 2009; Derom et al., 2015 ). Many participants increase the frequency, intensity and duration of exercise while training for the eevnt (Bowles, Rissel \& Bauman, 2006; Funk et al., 2011). An unambiguous causal link of this kind between events and an increase in sport participation is harder to demonstrate for event spectators (Ramchandani \& Coleman, 2012) and the pattern of any positive effects must be considered. These may be caused by an increase in the number of people participating or increases in the frequency of participation by people who are already active (Weed et al., 2015). The extent to which changes in participation are adopted permanently is also important (Weed et al., (2015).

Claims by sports administrators that athletic champions inspire people 'to have a go' and that medal 'moments' encourage people to 'get into sport' have been dismissed in the 
absence of empirical evidence (Weed et al., 2015). It is hard to find any evidence that hosting the Olympic Games contributes to an enduring increase in sport participation in the host nation (Coalter, 2004; Craig \& Bauman, 2014; Girginov \& Hills, 2008; Murphy \& Bauman, 2007) and some studies report that watching Olympic events may even demotivate spectators. The performance of elite athletes may even make spectators believe that the achievements they witness are beyond their level of competence thereby dimming their motivation to participate. This is consistent with Bandura's (1997) self-efficacy theory, an effect that may be reinforced if athletes are presented as superheroes in media campaigns. However, this argument underestimates people's capacity to moderate expectations and to strive for outcomes associated with other levels of participation. Further, the theory of planned behaviour (Ajen, 1991), suggests that the Olympic Games could have a positive impact on behavioural intentions by changing attitudes and subjective norms about sport participation. An interpretation drawing on social ecological theory would regard the Games as a sport participation 'target', with individual decisions about future behaviour based on dynamic interactions between the individual's personal attributes and his/her social and physical environment systems (Stokols, 1992). Targets are factors that are assumed to play a causal role in explaining and modifying behaviour (Derom et al., 2015). The high profile of an event might make beliefs about the benefits of sport more salient and encourage significant referents to support participation (Boardley, 2013). Groups that are already psychologically engaged with sport are susceptible to influence by sporting role models (Hindson et al., 1994). This effect is reinforced by the exposure-attitude hypothesis (Zajonc, 1968) which suggests that people are likely to have positive perceptions of events like the Olympic Games which command high levels of public attention.

Evidence of an Olympic effect was found in studies which examined the impact of the London Games in a non-hosting region (Leicestershire) and on non-traditional sports (fencing 
and judo). A study of an inter-business sporting competition in Leicestershire found that, in the period leading up to the 2012 Games, a large number of participants were interested in the Games $(71 \%)$ and their decision to join the programme was influenced by the Games; making them more interested in sport (33\%) and more aware of participation benefits $(30 \%)$ (Chen \& Henry, 2015). A study by Papous and Hayday (2015) of participation in fencing and judo found that grass-roots community programmes which took advantage of "unprecedented media coverage" (p. 1) associated with the Games were responsible for increases in club membership between 2007 and 2013. Both these studies lend support to the view that a demonstration effect may be most prevalent during the pre-Games 'pregnancy' period (Weed, 2008).

A trickle-down effect is partly based on the assumption that media coverage frames the way information is processed with favourable portrayals creating supportive attitudes (Ritchie, Shipway \& Chen, 2010) and it was widely believed that watching sport on television motivates viewers to take part in sports (Irlinger, 1994). For events to attract a large television audience, coverage needs to reflect viewer interests and values (Green, 2001) and the ability of the Olympic Games to symbolise issues and present a wide range of narratives (McDaniel \& Chalip, 2002) means that they retain an enduring ability to pull fragmented audiences onto the television networks (Slack, 1999). Other observations that the Games' “worldwide audience, relative infrequency, human drama and patriotic overtones make it highly desirable" (Kinney \& McDaniel, 1996, p. 251) retain contemporary relevance. A study by Lines (2007) made reference to 'media drenching' during a six week period that featured coverage of Wimbledon, the Atlanta Olympic Games and the European soccer tournament. The study found a temporary increase in the desire to participate among young people who watched the events. Another study found an increase in junior registrations in 
rugby clubs that was attributed to sport development programmes which took advantage of the exposure associated with the 2003 Rugby World Cup (Frawley \& Cush, 2011).

\section{Event satisfaction}

It is not merely being a participant or spectator of an event which influences future intentions but the level of satisfaction that is gained. Customer satisfaction has featured extensively in the marketing literature where studies have drawn on early work which considered satisfaction to be a product of the confirmation or disconfirmation of preconsumptive expectations (Oliver, 1980) and the cognitive processing of affect (Oliver, 1993). An influential paper by Madrigal (1995) discussed the determinants of event satisfaction and, more recently, a need to recognise the unique characteristics of sport on satisfaction has been expressed (van Leeuwen, Quick and Daniel, 2002). Spectator satisfaction has been defined as a "pleasurable, fulfilment response to the entertainment of a sport competition" (Yoshida \& James, 2010, p. 340). Some studies have found that the core sport product, associated with the game and its outcomes, had the strongest effect on satisfaction (Brady, Vorhees, Cronin, \& Bourdieu, 2006; Tsuji, Bennet, \& Zhang, 2007) while others have found that environmental factors are more predictive of satisfaction (Greenwell, Fink, \& Pastore, 2002). All these factors may be exaggerated in Olympic events because of their added importance and because organisers go to considerable lengths to create impressive settings. The result is $\underline{\text { a spectacle - which seduces, entertains and awes spectators. These are not merely produced }}$ by athletes and organisers: Chappelet (2013) suggests it is the active contributions of spectators that turn sports competitions into emotionally charged spectacles.

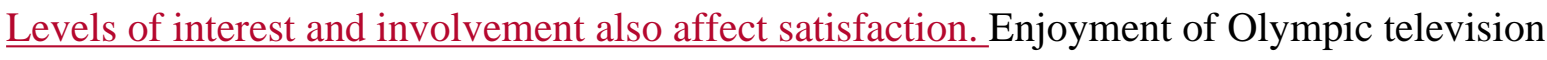
coverage was found to be partly a function of the level of viewer interest in the Games 
(McDaniel \& Chalip, 2002) and visitors who were highly involved in an event's programs and activities were more likely to be satisfied and to express an intention to return in the future (Lee \& Beeler, 2009). Involvement refers to levels of psychological connection (Funk, Ridinger, \& Moorman, 2004), perceptions about personal relevance (Kyle \& Chick, 2002) and the degree to which a person is committed to an object, activity, place or experience (Gross \& Brown, 2008). Based on the emotional intensity of events, the range of meanings ascribed to them and their perceived quality, satisfaction with the sport event experience has been found to have the potential to foster the development of positive attitudes toward activity commitment (Funk et al., 2011, p. 255) and engagement in future activity (Tian-Cole, Crompton \& Wilson, 2002).

\section{Method}

The review has demonstrated the need for a better understanding of the relationship between events and their impact on sport participation. The London 2012 Olympic Games presented an excellent opportunity to examine propositions about an inspirational demonstration effect. London 2012 events were consumed mainly by a remote audience but organisers also went to considerable lengths to enhance the experiences of those attending in person (Chappelet, 2013; Jones, 2013). The swimming competition was chosen as the focus for the study due to the appeal of the sport as an Olympic spectator event and because swimming is also an activity that has high rates of participation in the general population.

\section{Hypothetical Model}

The research was organised around a hypothesized model that was rigorously tested using advanced quantitative data analysis techniques. Figure 1 illustrates the full model and presents the theorized causal relationships among the constructs adopted in this study. The 
satisfaction, attendance and participation intention constructs are hypothesized as first-order reflective constructs.

(Figure 1 near here)

Based on the literature review, it was assumed that spectators' perceptions and evaluations of the event and thus their level of satisfaction have a positive, direct impact on their future event attendance and participation intentions with the sport. This leads to the hypotheses:

H1: Spectators' satisfaction will have a positive impact on their future attendance of the sport.

H2: Spectators' satisfaction will have a positive impact on their future participation in the sport.

To examine differences between spectators who watched the swimming on television and those who watched the activity on site, the following hypothesis is presented based on proposed variations in relationships between the two groups concerning satisfaction, and event attendance and participation intentions:

H3: The relationships between satisfaction, attendance, and participation intentions will differ across television and on-site spectators.

\section{Measurement instrument}

Data was gathered via detailed questionnaires that were distributed in person at the venues. Respondents were asked to indicate whether they had been swimming regularly during the past 12 months. Additional indicators of behavioural intensity were measured by questions about the number of ticketed events attended at the Games and the amount of television 
coverage of the Games that was watched by the respective samples. Respondents were required to indicate their level of agreement with statements, on a 7-point scale $(1=$ strongly disagree; 7 = strongly agree), for the questions that measured the key constructs. Three questions, based on the work of Alexandris, Zahariadis, Tsorbatzoudis and Grouios (2004) and Oliver (1997), were used to capture context-specific measures of satisfaction associated with anchor, success and global attributions. Consistent with the approach adopted by Derom et al. (2015), respondents were able to indicate intentions to participate in sport at different levels of engagement (for fun, for fitness and to compete). In addition, questions were included about intentions to attend swimming events or watch swimming events on television.

\section{Data collection}

The survey was conducted at two sites to gain access to respondents associated with the alternative forms of spectating. Questionnaires were distributed at the London 2012 Aquatics Centre which was the venue for swimming events - described as "the London Olympic's most majestic space, the most potent, the most charged" (Moore, 2011, p. 31). Six trained research assistants were assigned to locations in the venue where spectators congregated and had time to complete and return the questionnaire. Respondents were randomly selected, given a questionnaire and a clipboard and, as an incentive, were able to keep the Olympic souvenir pen that was provided to complete the questionnaire. One hundred and eighty-five questionnaires were completed on July 29, 2012 during or immediately after the morning and evening sessions. On August 27, 135 questionnaires were completed by people at the Life Centre in Plymouth, Devon. The Centre is located in south-west England, approximately 200 miles from London. It was selected because it was considered to be an ideal venue to obtain a sample of people with different levels of involvement in swimming and, due to the timing of the survey, it was expected that it would be possible to report recollections of the Games 
without difficulty. The multi-purpose leisure facility, which had opened in March, 2012, included a ten lane, 50 metre pool and a diving pool. It was the home pool of the high profile British diver, Tom Daley, an Olympic medallist, and was used as a training venue by national swimming and diving teams, prior to the 2012 Games. One of the main aims of the Centre was to improve the health and well-being of the people of Plymouth and, in the foyer, a Sport England plaque proclaimed the Centre to be 'an iconic facility - inspired by London 2012'. Respondents were approached in the foyer area throughout the day in order to capture a (quasi) representative sample of people attending the different classes, training sessions and programmed activities.

\section{Data analysis}

Initially, the data were analysed using SPSS v. 21 to impute the missing values and generate summary statistics for both samples (on-site and television spectators). Exploratory factor analysis (EFA) and reliability tests were used to examine the dimensionality and internal consistency for each of the first-order reflective constructs considered separately (i.e. for satisfaction, attendance, and participation intentions). EFA was then used to verify whether each construct was sufficient to influence the indicators identified in previous literature and proposed in the context of the present study (Hurley, Scandura, Schriesheim, Brannich, Seers, \& Vandenberg, 1997).

After verifying the unidimensionality and internal consistency of each factor, the structural relationships (see Figure 1) among the factors were analysed using partial least squares structural equation modelling (PLS-SEM). PLS-SEM was adopted due to the technique's ability to accommodate the analysis of complex models and instances where some of the constructs have a small number of indicators (Hulland, Ryan, \& Rayner, 2010). The validated model was separately examined across each of the samples ( $\mathrm{Gr}$ 1: people who watched the event on television in Plymouth; Gr 2: people who watched the activity on site at 
the Aquatics Centre) to test for any differences in structural relationships (see Chin, 1998; Keil, Tan, Wei, Saarinen, Tuunainen \& Wassenaar, 2000). PLS compares each of the path coefficients between the groups in a step-wise order, using 1) multi-group $t$-test and 2) permutation tests (Vinzi \& Russolillo, 2010). The multi-group $t$-test assumes the normality of the data whereas the permutation test uses bootstrap sampling techniques to generate confidence intervals and $p$-values. The permutation tests often provide more accurate results than multi-group $t$-tests, especially in the case of normality violations and small samples (Henseler \& Fassott, 2010). Both tests use unstandardized data.

\section{Results}

\section{Summary statistics}

The profile of the two samples was similar in terms of their gender, age, and employment distributions. For spectators at the Aquatics Centre, $49 \%(n=90)$ were males $(51 \%$ or $n=95$ females), approximately half of the respondents (49\%; $n=91)$ were between 30 and 49 years old, and the majority (75\%; $\mathrm{n}=139)$ were employed. Meanwhile, for the Plymouth sample, $48 \%(n=63)$ were males compared to $52 \%(n=68)$ females, $56 \%(n=73)$ were between 30 and 49 years old, and approximately 64\% $(n=84)$ were employed. More people in the London sample were in full-time, permanent employment; $63 \%$ compared to $47 \%$ in Plymouth. The Plymouth sample had a higher proportion of retired people (15\% compared to 5\%).

In terms of geographic distribution, $64 \%(n=118)$ of the Aquatics Centre spectators were from the UK, almost half of whom $(n=49)$ were residents of London. The percentage of international visitors (36\%) was relatively high compared to other Olympic events, as was the percentage who had attended another Olympic Games (21\%). Only two of the spectators in $\underline{\text { the Plymouth sample were international visitors, with most }(\mathrm{n}=109) \text { living in Plymouth or }}$ 
other places in Devon. Very few people in the Plymouth sample had prior, live experience of the Olympic Games (99\% had never attended an Olympic event) but nine people had gone to the London 2012 Olympics and two had attended the swimming.

The majority of the Aquatics Centre spectators were spending at least 2 nights in London while attending the games $(70 \% ; \mathrm{n}=129)$, as opposed to $30 \%$ who were either on a day trip or spending only one night. Most were accompanied by 1 to 3 people $(64 \% ; n=118)$, and very few were attending the Games alone $(5 \% ; n=10)$ or with more than 5 people $(5 \% ; n=9)$. The majority of the Aquatics Centre spectators $(74 \%$; $n=137)$ were accompanied by their partner, children, or other relatives, while the remainder $(26 \% ; n=48)$ were accompanied by friends or colleagues.

The sample collected at the Leisure Centre in Plymouth indicated a higher level of participation in swimming than the sample collected at the London Aquatics Centre (Table 1). Respondents in both samples showed high levels of event satisfaction with mean scores for the three measures shown in Table 1. The results from the ANOVA demonstrated significant differences in terms of satisfaction and future intentions (participation and attendance) with respondents from the London sample showing higher mean scores on these items at the .05 significance level (see Table 1). The majority of the respondents from the Plymouth sample (approximately 72\%) watched live coverage of the Olympics from 1 to 4 hours a day and approximately $70 \%$ watched live coverage of the swimming events for 4 days or more (of the 8 days on which the event was held). An ANOVA was performed to examine differences in mean scores for event satisfaction, and intentions in terms of television viewing patterns for the Plymouth sample. The results showed significant differences for the satisfaction scores across viewing practices at the .05 significance level. Respondents who watched more hours of Games coverage and spent more days watching the 
swimming had a higher mean score on satisfaction (see Table 2). For the London sample, the results showed that almost half (approximately 45\%) attended between two and five ticketed Olympic events, while an equal percentage (approximately 27\% each) attended either one ticketed session or more than five sessions. An ANOVA revealed that there were no significant differences in mean scores. In other words, the number of events attended was not associated with the level of event satisfaction nor with the intentions of respondents from the London sample. Finally, ANOVA was used to determine possible differences in mean scores of satisfaction, attendance, and participation intentions across gender, age, and employment in both of the samples (e.g. the London Aquatic Center and Plymouth).ANOVA was used to check whether it was necessary to control for demographic variables when examining the relationships between satisfaction and intentions (both attendance and participation) in Figure 1. The results revealed that there were no significant differences in mean scores across the three demographic variables for the two samples, suggesting that neither age, gender nor employment affected the level of satisfaction or the intentions to attend/participate in sports.

(Table 1 near here)

(Table 2 near here)

\section{Exploratory block factor and reliability analysis}

Results of the principal component analysis (PCA) on the unstandardized data of the blocks of variables (satisfaction, participation, and attendance intention constructs) found that the loadings for all constructs were $>0.7$ with an eigenvalue greater than 1 , supporting their 
unidimensionality (see Table 3). The Cronbach's alpha and Dillon-Goldstein's rho were also used to determine the internal consistency of the blocks. In both tests, results were higher than the lower limit of 0.6 (Nunnaly \& Bernstein, 1994), indicating good scale reliability and further supporting the unidimensionality and reflective scheme of the factors (Table 3).

(Table 3 near here)

\section{PLS-SEM analysis}

The model was examined through PLS-SEM using XLSTAT software (Addinsoft, 2011) on the full dataset of the unstandardized data using Mode A (reflective scheme) for the constructs (Figure 1). The weights of the inner model were estimated using the centroid method (Chin, 1998). The results found that satisfaction, participation, and attendance intentions were all unidimensional with loadings for each construct again $>0.7$. Furthermore, the bootstrap test showed high significance levels for all loadings (bootstrap-based empirical 95\% confidence interval does not include zero; Table 4). Table 4 shows that the average variance extracted (AVE) for each construct also exceeded the required 0.5 threshold. This result indicated that more than $50 \%$ of the indicators' variance can be captured by the construct (Chin, 1998), further supporting the convergent validity of the model's constructs.

Discriminant validity is supported when the AVE of a construct and its indicators exceed the shared variance with every other construct of the model (Fornell \& Larcker, 1981). This was the case in the model in the present study, in which it was found that the AVE for each construct was greater than the squared correlation coefficient of that construct with every other construct of the model. 
(Table 4 near here)

In an analysis of the inner model (inner relationships among the constructs), all hypothesized causal relationships were found to be significant, except for the impact of satisfaction on participation (see Figure 2). The results of the path coefficients indicated that satisfaction has a positive effect on attendance intention (supporting hypothesis H1). However, a significant relationship between satisfaction and participation was not found (meaning hypothesis $\mathrm{H} 2$ is unsupported). In addition, the r-square for the attendance construct (see Figure 2) is greater than 20\%, suggesting that spectators' satisfaction can explain more than $20 \%$ of the attendance construct, which is a desired result in this case as it supports the model's prediction validity (see Chin, 1998).

(Figure 2 near here)

We cross-validated the model across the two samples separately using multigroup and permutation tests (Vinzi \& Russolillo, 2010). Results from both tests are shown in Table 5. The effect of satisfaction on future attendance was found to be equal across both groups, the effect of satisfaction on participation was positive and significant (reg coeff $=0.133$ ) for those who watched the event live at the venue but it was non-significant (reg coeff $=0.040$ ) for those who watched the competition on television. These results - which support hypothesis H3 - are further explained in the discussion and conclusions section.

(Table 5 near here)

\section{Discussion and conclusions}


Our findings indicate that people who watched the swimming competition that was held at the London Olympic Games enjoyed very satisfying experiences. This was true for both people at the Aquatics Centre and people who watched the event on television. No significant differences were found among the London sample due to variations in the number of ticketed events. Satisfaction was not influenced by behavioural intensity, in this context. However, there is clearly scope for event satisfaction to be examined in more detail and the relevant $\underline{\text { literature exhibits a notable lack of longitudinal research. It would be valuable to capture }}$ $\underline{\text { relevant expectations and measures of satisfaction before, during and after event experiences. }}$

Among the Plymouth sample, there was a high level of behavioural commitment to watching the televised coverage of the Olympic Games and the swimming events. Ninety-two percent of the respondents spent at least one hour every day watching the Games with one-in-five spending more than four hours each day. This finding is not surprising as the London Olympics were the biggest national television event in the UK since current measuring systems began more than a decade ago, with 51.9 million (nine out of 10 people) watching coverage on the BBC (IOC, 2012). Only six percent did not watch live coverage of a swimming event and almost half of the sample (47\%) watched live coverage on six or more of the eight days of swimming competition. Significantly, the longer that people watched the television coverage, the more satisfied were they with the experience. The findings provide evidence of the ongoing ability of the Olympic Games to attract a large, committed and satisfied television audience and confirm the appeal of swimming as a spectator event.

Both samples were found to have distinctive characteristics and cannot be treated as representative of broader populations. People in the Plymouth sample were expressing a level of sport participation by visiting the Centre however, it is important to acknowledge that a 
wide variety of users were included in the sample. People of all ages and a range of skill levels were represented and the sample included people who were accompanying family and friends and not using the pool. Significantly, the Plymouth sample served as a benchmark against which the profile of Olympic spectators at the Aquatics Centre in London could be compared. So, it is noteworthy that there was a significant difference between the groups in terms of previous participation in swimming. The London sample expressed a lower level of participation in swimming in the previous twelve months. This suggests that Olympic spectators are not as actively involved in the sport they watch as people who visit a sport facility. There is scope to improve their level of participation from a relatively low base level.

Our findings indicated that there was a positive relationship between event satisfaction and intention to watch swimming events in the future (as a spectator and on television), but this was not true for event satisfaction and intention to participate in swimming. Fundamentally, a demonstration effect associated directly with watching Olympic events was not found. However, there was a difference between the two groups. People who were satisfied with the live experience at the Aquatics Centre were more likely to participate in swimming in the future than people in the Plymouth sample. Thus, although a relationship between event satisfaction and sport participation was not found, there is evidence that the impact of attending a live event may be greater than watching the event on television. Our study focussed on mass participation effects and it is important to acknowledge that London 2012 events may have inspired a small number of people to become elite swimmers. Future research could try to identify this type of demonstration effect which was beyond the scope and timeframe of this study.

The findings presented here support the proposition that "the potential of events to inspire audiences is higher amongst those who attend events rather than who experience them elsewhere" (Ramchandani \& Coleman, 2012, p. 267) although they also suggest that this may 
be partly due to differences in the level of prior participation. So, when interpreting the findings it is important to recognise the potential role played by other factors. For instance, situational variables may have been relevant in the different settings. It is not possible to determine the importance of factors such as the symbolism at the Olympic Park, the atmosphere in the Aquatics Centre, nor the local associations with the Olympics that existed at the Life Centre in Plymouth where the survey was conducted. Brochures at the Life Centre explained

"as part of the Olympic legacy we have decided to fit as many Olympic sports in the Life Centre as we can. The idea is for armchair supporters or anyone who may have been inspired by the Games to come and try a new sport".

In terms of legacy, this can be regarded as an example of additionality; a thematic emphasis that would not have been possible in the absence of the Games (Weed, 2014). In addition, the presence of Olympic heroes such as Tom Daley at the pool in Plymouth may have enhanced the effect of local relatedness which has been suggested as a potentially influential factor in the motivation to participate in sport (Hindson et al., 1994; Weed et al., 2015). However, as acknowledged by Potwarka, (2015), "little is known about the factors that might make certain athletes (and images and narratives associated with them) particularly encouraging versus discouraging" (p. 87).

Changes in sport participation are the result of "complex and not well understood interactions" (Coalter, 2004, p. 108) and the design of future research should try to accommodate some of this complexity. Lessons from the research described in this paper suggest that a study with similar objectives could distribute questionnaires at the venue during an event and ask other people to complete the questionnaire, at the same time, in their homes when watching the event on television. Ideally, the same respondents would be 
contacted six months later to monitor any changes in their participation in sport. To complement this longitudinal approach, a qualitative component could be employed to explore perceptions of the role played by social norms and role models as determinants of the importance placed on sport participation. The importance of 'being there' (Weed, 2007) could be further evaluated by comparing factors such as the excitement of the stadium with the conviviality of the home environment.

A final and sobering observation on this subject comes from newspaper reports which were published in July, 2015, to mark the tenth anniversary of London being awarded the 2012 Games. Just three of the 26 Olympic sports had seen increases in participation since 2012-13 and, since the Games, nearly 700, 000 fewer adults were playing nationally funded sports (Gibson, 2015). Swimming, which registered the biggest decline with a reduction of 729,000 people in the previous decade (Conn, 2015), had been disproportionately affected by local authority funding cuts (Gibson, 2015). One of the reports concluded, "The opening ceremony of the $£ 9.3$ bn Olympics broadcast to the world modern Britain’s NHS and social advances, even while the legacy of sports facilities built over more than a century was being relentlessly undermined, under assault by a thousand cuts" (Conn, 2015). Inadequate access to sport facilities can impede the realisation of a demonstration effect, limiting the sports participation legacies of mega-events. To turn sport participation legacies from rhetoric into reality, any inspirational effect must be accompanied by the capacity to satisfy any new demand.

\section{References}

Addinsoft. (2011), XLSTAT Pro version 2011.3. http://www.xlstat.com. 
Ajzen, I. (1991). The theory of planned behaviour. Organizational Behavior and Human Decision Processes, 50, 179-211.

Alexandris, K., Zahariadis, P., Tsorbatzoudis, C., \& Grouios, G. (2004). An empirical investigation of the relationships among service quality, customer satisfaction and psychological commitment in a health club context. European Sport Management Quarterly, 4, 36-52.

Bandura, A. (1997). Self-efficacy: the exercise of control. New York: W. H. Freeman.

Bauman, A., Murphy, N., \& Lane, A. (2009). The role of community programmes and mass events in promoting physical activity to patients. British Journal of Sports Medicine, 43, 44-46.

Boardley, I. D. (2013). Can viewing London 2012 influence sport participation? - a viewpoint based on relevant theory. International Journal of Sport Policy and Politics, 5(2), 245-256.

Bowles, H., Rissel, C., \& Bauman, A. (2006). Mass community cycling events: who participates and is their behaviour influenced by participation? International Journal of Behavioral Nutrition and Physical Activity, 3, 39.

Brady, M. K., Vorhees, J.J., Cronin, J., Jr., \& Bourdeau, B.L. (2006). The good guys don't always win: the effect of valence on service perceptions and consequences. Journal of Services Marketing, 20, 83-91.

Bullough, S. J. (2012). A new look at the latent demand for sport and its potential to deliver a positive legacy for London 2012. International Journal of Sport Policy and Politics, 4(1), $39-54$.

Carmichael, F., Grix, J., \& Marques, D. P. (2013). The Olympic legacy and participation in sport: an interim assessment of Sport England's Active People Survey for sports studies research. International Journal of Sport Policy and Politics, 5(2), 229-44. 
Chapman, M. (2012). British Gas readies ‘free swim’ Olympic campaign. Marketing. http://www.marketingmagazine.co.uk/article/1134133/british-gas-readies-free-swimolympic-campaign. Viewed October 22, 2015.

Chappelet, J-L. (2013) Spectating The Games. In V. Girginov. Handbook of the London 2012 Olympic and Paralympic Games: Volume Two: Celebrating the Games (pp. 141-153). Abingdon: Routledge.

Chen, S., \& Henry, I. (2015). Evaluating the London 2012 Games' impact on sport participation in a non-hosting region: a practical application of realist evaluation. Leisure Studies, doi: 10.1080/02614367.2015.1040827

Chin, W. W. (1998). The partial least squares approach to structural equation modeling. In G. Marcoulides (Ed.), Modern methods for business research (pp. 295-336). Mahwah: Lawrence Erlbaum Associates.

Coalter, F. (2004). Stuck in the blocks? A sustainable sporting legacy. In A. Vigor, M. Mean, \& C. Tims (Eds.), After the gold rush: a sustainable Olympics for London. London: Institute for Public Policy research/Demos. pp. 93-94.

Conn, D. (2015). Olympic legacy failure: sports centres under assault by thousand council cuts. http://www.theguardian.com/sport/2015/jul/05/Olympic-legacy-failure-sports-centrecouncil-cuts. Viewed July 6, 2015.

Craig, C. L., \& Bauman, A. E. (2014). The impact of the Vancouver Winter Olympics on population level physical activity and sport participation among Canadian children and adolescents: population based study. International Journal of Behavioral Nutrition and Physical Activity, 11(1), 1-9.

Derom, I., Van Wynsberghe., \& Scheerder, J. (2015). Maintaining physical activity postevent? Case of the Tour of Flanders Cyclo in Belgium. Annals of Leisure Research,18(1), 25-47. 
Devine, C. (2013). London 2012 Olympic legacy: a big sporting society? International Journal of Sport Policy and Politics, 5(2), 257-279.

Fornell, C., \& Larcker, D.F. (1981). Evaluating structural equation models with unobservable variables and measurement error. Journal of Marketing Research, 18, 39-50.

Frawley, S., \& Cush, A. (2011). Major sports events and participation legacy: the case of the 2003 Rugby World Cup. Managing Leisure, 16(1), 65-76.

Funk, D. C., Ridinger, L. L., \& Moorman, A. M. (2004). Exploring the origins of involvement: understanding the relationship between consumer motives and involvement with professional sport. Leisure Sciences, 26, 35-61.

Funk, D., Jordan, J., Ridinger, L., \& Kaplanidou, K. (2011). Capacity of mass participation sport events for the development of active commitment and future exercise intention. Leisure Sciences, 33, 250-268.

Gibson, O. (2015). Olympic legacy failure: sporting numbers plummet amid confusion and blame. http://www. theguardian.com/sport/2015/jul/05/Olympic-legacy-failure-sportingnumbers-plummets. Viewed July 6, 2015.

Girginov, V., \& Hills, L. (2008). A sustainable sports legacy: creating a link between the London Olympics and sports participation. The International Journal of the History of Sport, 25(14), 2091-2116.

Green, B. C. (2001). Leveraging subculture and identity to promote sport events. Sport Management Review, 4, 1-19.

Greenwell, T. C., Fink, J. S., \& Pastore, D. L. (2002). Assessing the influence of the physical sports facility on customer satisfaction within the context of the service experience. Sport Management Review, 5, 129-148. 
Gross, M. J. \& Brown, G. (2008). An empirical structural model of tourists and places: progressing involvement and place attachment into tourism. Tourism Management, 29, $1141-1151$.

Henseler, J., \& Fassott, G. (2010). Testing moderating effects in PLS path models: an illustration of available procedures. In V. C. Esposito Vinzi, Wynne W.; Henseler, Jörg; Wang, Huiwen (Ed.), Handbook of Partial Least Squares: Concepts, Methods and Applications (Springer Handbooks of Computational Statistics Series) (Vol. 2, pp. 713735). Heidelberg, Dordrecht, London, New York: Springer.

Hindson, A., Gidlow, B., \& Peebles, C. (1994). The trickle down effect of top level sport: myth or reality? A case study of the Olympics. Australian Journal of Leisure and Recreation, 4, 16-24.

Hogan, K., \& Norton, K. (2000). The 'price' of Olympic gold. Journal of Science and Motivation in Sport, 3, 203-218.

Hulland J, Ryan MJ, Rayner RK (2010) Modelling customer satisfaction: a comparative performance evaluation of covariance structure analysis versus partial least squares. In: Esposito Vinzi V, Chin WW, Henseler J, Wang H (Ed), Handbook of Partial Least Squares: Concepts, Methods and Applications (Springer Handbooks of Computational Statistics Series) (Vol. 2, pp.307-325). Heidelberg, Dordrecht, London, New York: Springer.

Hurley, A. E., Scandura, T. A., Schriesheim, C. A., Brannick, M. T., Seers, A., \& Vandenberg, R. J. (1997). Exploratory and confirmatory factor analysis: guidelines, issues, and alternatives. Journal of Organizational Behavior, 18, 667-683.

International Olympic Committee. (2012). Marketing Report London 2012. http://www.olympic.org/Documents/IOC_Marketing/London_2012/LR_IOC_Marketing_

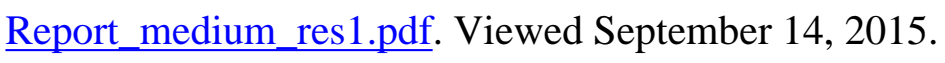


Irlinger, P. (1994). The contribution of televised sports to the spread of sports activities. International Review for Sociology of Sport, 29(2), 201-209.

Jones, I. (2013) Visiting the Games; Spectators, Fans and Behaviours. In V. Girginov (Ed.) Handbook of the London 2012 Olympic and Paralympic Games: Volume Two: Celebrating the Games. (pp.110-122) Abingdon: Routledge.

Keil, M., Tan, B. C. Y., Wei, K.-K., Saarinen, T., Tuunainen, V., and Wassenaar, A. (2000). A cross-cultural study on escalation of commitment behavior in software projects. Management Information Systems Quarterly, 24(2):299-325.

Kinney, L., and McDaniel, S. R. (1996). Strategic implications of attitude-toward-the-ad in leveraging event sponsorships. Journal of Sport Management, 10, 250-261.

Kyle, G, T., \& Chick, G. (2002). The social nature of leisure involvement. Journal of Leisure Research, 34(4), 426-448.

Lee, J. \& Beeler, C. (2009). An investigation of predictors of satisfaction and future intention: links to motivation, involvement, and service quality in a local festival. Event Management, 13, 17-29.

Lines, G. (2007). The impact of media sport events on the active participation of young people and some implications for PE pedagogy. Sport, Education and Society, 12(4), 349366.

Madrigal, R. (1995). Cognitive and affective determinants of fan satisfaction with sporting event attendance. Journal of Leisure Research, 27, 205-227.

McDaniel, S. R. \& Chalip, L. (2002). Effects of commercialism and nationalism on enjoyment of an event telecast: lessons from the Atlanta Olympics. European Sport Management Quarterly, 2, 3-22.

Moore, R. (2011). Olympics Aquatic Centre - a review. The Observer, July 31, 2011. 
Murphy, N. M., \& Bauman, A. (2007). Mass sporting and physical activity events: are they bread and circuses or public health interventions to increase population levels of physical activity? Journal of Physical Activity and Health, 4, 193-202.

Nunnally, J. C., \& Bernstein, I.H. (1994). Psychometric Theory. New York: McGraw-Hill.

Oliver, R. L. (1980). A cognitive model of the antecedents and consequences of satisfaction decisions. Journal of Marketing Research, 17, 460-469.

Oliver, R. L. (1993). Cognitive, affective, and attribute bases of the satisfaction response. Journal of Consumer Research, 20, 418-430.

Pappous, A., \& Hayday, E. J. (2015). A case investigating the impact of the London 2012 Olympic and Paralympic Games on participation in two non-traditional English sport, Judo and Fencing. Leisure Studies, doi:10.1080/02614367.2015.1035314

Parent, M. M. (2008). Mega sporting events and sports development. In V. Girginov (Ed) Management of Sports Development. London: Routledge pp. 147-163.

Pocket-lint (2012). British Gas turns Team GB swimmers into superheroes. http://www.pocket-lint.com/news/115566-british-gas-team-gb-superheroes. Viewed October 22, 2015.

Potwarka, L. R. (2015). Exploring physical activity intention as a response to the Vancouver Olympics: an application and extension of the theory of planned behavior. Event Management, 19, 73-92.

Quilter, J. (2012). British Gas signs $£ 15$ million British Swimming sponsorship. BrandRepublic. http://www.brandrepublic.com/article/890316/british-gas-signs-15mbritish-swimming-sponsorship. Viewed October 22, 2015.

Ramchandani, G. M., \& Coleman, R. J. (2012). The inspirational effects of three major sport events. International Journal of Event and Festival Management, 3(3), 257-271. 
Ritchie, B. W., Shipway, R., \& Chien, P. M. (2010). The role of the media in influencing residents' support for the 2012 Olympic Games. International Journal of Event and Festival Management, 1(3), 202-219.

Rowe, N. F. (2009). The Active People Survey: a catalyst for transforming evidence-based sport policy in England. International Journal of Sport Policy, 1(1), 89-98.

Silk, M. (2011). Towards a sociological analysis of London 2012. Sociology, 45(4), 733-748.

Slack, T. (1999). An interview with Alan Pascoe. International Journal of Sports Marketing and Sponsorship, 1, 10-18.

Smith, A. (2012). Events and Urban Regeneration: the Strategic Use of Events to Revitalise Cities. Abingdon: Routledge.

Stokols, D. (1992). Establishing and maintaining healthy environments : toward a social ecology of health promotion. American Psychologist, 47(1), 6-22.

Tian-Cole, S., Crompton, J. L., \& Wilson, V. L. (2002). An empirical investigation of the relationships between service quality, satisfaction and behavioural intentions among visitors to a wildlife refuge. Journal of Leisure Research, 349!), 1-24.

Tsuji, Y., Bennett, G., \& Zhang, J. (2007). Consumer satisfaction with an action sports event. Sport Marketing Quarterly, 16, 199-208.

Van Leeuwen, L., Quick, S., \& Daniel, D. (2002). The sport spectator satisfaction model: a conceptual framework for understanding the satisfaction of spectators. Sport Management Review, 5, 99-128.

Vinzi, V. E., \& Russolillo, G (2010). Partial least squares path modeling and regression. In Y. S.E. Wegman, and D. Scott (Ed.), Wiley interdisciplinary reviews: computational statistics. New York: Wiley.

Weed, M. (2007). The pub as a virtual football fandom venue: an alternative to 'being there'? Soccer and Society, 8(2/3), 399-414. 
Weed, M. (2008). Olympic tourism. Oxford: Elsevier.

Weed, M. (2014). Is tourism a legitimate legacy from the Olympic and Paralympic Games? An analysis of London 2012 legacy strategy using programme theory. Journal of Sport \& Tourism, 19(2), 101-126.

Weed, M., Coren, E., Fiore, J., Wellard, I., Chatziefstathiou, D., Mansfield, L., \& Dowse, S. (2015). The Olympic Games and raising sport participation: a systematic review of evidence and an interrogation of policy for a demonstration effect. European Sport Management Quarterly, 15(2), 195-226.

World Health Organisation. (2015). Physical Activity. Fact Sheet n0 385. http://www.who.int/mediacentre/factsheets/fs385/en/. Viewed November 26, 2015.

Yoshida, M., \& James, J. D. (2010). Customer satisfaction with game and service experiences: antecedents and consequences. Journal of Sport Management, 24, 338- 361.

Zajonc, R. B. (1968). The attitudinal effects of mere exposure. Journal of Personality and Social Psychology, 9, 1-27. 
Table 1. Summary statistics of the Plymouth vs. London samples

\begin{tabular}{|c|c|c|c|c|c|}
\hline \multirow{2}{*}{$\begin{array}{l}\text { Variable } \\
\text { label }\end{array}$} & \multirow[b]{2}{*}{ Items } & \multicolumn{2}{|c|}{ Plymouth $(\mathrm{N}=131)$} & \multicolumn{2}{|c|}{ London $(\mathrm{N}=185)$} \\
\hline & & Mean & $\begin{array}{c}\text { Std. } \\
\text { deviation }\end{array}$ & Mean & $\begin{array}{c}\text { Std. } \\
\text { deviation }\end{array}$ \\
\hline Particp & In the past year I have been swimming regularly & 5.24 & 1.96 & 3.73 & 2.01 \\
\hline S1 & $\begin{array}{l}\text { I am glad I decided to attend the London Olympic } \\
\text { Games }\end{array}$ & 6.42 & 0.97 & 6.72 & 0.88 \\
\hline $\mathrm{S} 2$ & It was a good decision to watch the swimming event & 6.23 & 1.09 & 6.59 & 0.92 \\
\hline S3 & I was satisfied with my experience at the event today & 5.65 & 1.65 & 6.49 & 1.06 \\
\hline Particip1 & I will swim regularly for fun & 4.59 & 1.55 & 5.72 & 1.90 \\
\hline Particip2 & I will swim regularly for fitness & 4.55 & 1.66 & 5.87 & 1.52 \\
\hline Particip3 & I will compete in swimming events & 2.44 & 1.99 & 2.42 & 1.95 \\
\hline Att1 & I will attend swimming events as a spectator & 3.66 & 2.01 & 4.37 & 1.88 \\
\hline Att2 & I will watch swimming events on television & 4.99 & 1.62 & 5.49 & 1.90 \\
\hline & & Frequency & Percent & Frequency & Percent \\
\hline & $\begin{array}{l}\text { During the } 2012 \text { Olympic Games, approximately } \\
\text { how much time each day did you spend watching } \\
\text { television coverage of events? }\end{array}$ & & & & \\
\hline & less than 1 hour & 10 & $7.63 \%$ & - & - \\
\hline & $1-2$ hours & 42 & $32.06 \%$ & - & - \\
\hline & more than $2-4$ hours & 52 & $39.69 \%$ & - & - \\
\hline & more than $4-6$ hours & 22 & $16.79 \%$ & - & - \\
\hline & more than 6 hours & 5 & $3.82 \%$ & - & - \\
\hline & Total & 131 & $100.00 \%$ & - & - \\
\hline & $\begin{array}{l}\text { On how many days did you watch live TV coverage } \\
\text { of the swimming events? }\end{array}$ & & & & \\
\hline & 0 & 8 & $6.11 \%$ & - & - \\
\hline & 1 & 3 & $2.29 \%$ & - & - \\
\hline & 2 & 16 & $12.21 \%$ & - & - \\
\hline & 3 & 13 & $9.92 \%$ & - & - \\
\hline & 4 & 11 & $8.40 \%$ & - & - \\
\hline & 5 & 18 & $13.74 \%$ & - & - \\
\hline & 6 & 12 & $9.16 \%$ & - & - \\
\hline & 7 & 4 & $3.05 \%$ & - & - \\
\hline & 8 & 46 & $35.11 \%$ & - & - \\
\hline & Total & 131 & $100.00 \%$ & - & - \\
\hline & $\begin{array}{l}\text { How many ticketed sessions did you attend during } \\
\text { the } 2012 \text { Olympic Games }\end{array}$ & & & & \\
\hline & 1 & - & - & 50 & $27.03 \%$ \\
\hline & 2 & - & - & 31 & $16.76 \%$ \\
\hline & 3 & - & - & 31 & $16.76 \%$ \\
\hline & 4 & - & - & 17 & $9.19 \%$ \\
\hline & 5 & - & - & 6 & $3.24 \%$ \\
\hline & more than 5 & - & - & 50 & $27.03 \%$ \\
\hline & Total & - & - & 185 & $100.00 \%$ \\
\hline
\end{tabular}

Note: Bolded means values denote significant differences across the two samples at the .05 significance level 
Table 2. ANOVA results for differences in spectators' satisfaction level in terms of TV viewing patterns

\begin{tabular}{|c|c|c|c|c|c|}
\hline & \multicolumn{3}{|c|}{ ANOVA } \\
\hline TV Viewing Variable & $\begin{array}{c}\text { Satisfaction } \\
\text { Items }\end{array}$ & Variable categories & Mean & $\mathbf{F}$ & sig. \\
\hline \multirow{3}{*}{$\begin{array}{l}\text { During the } 2012 \text { Olympic Games, approximately how much } \\
\text { time each day did you spend watching television coverage of } \\
\text { events? }\end{array}$} & $\mathrm{S} 1$ & $\begin{array}{l}\text { less than } 1 \text { hour } \\
1-2 \text { hours } \\
\text { more than } 2-4 \text { hours } \\
\text { more than } 4-6 \text { hours } \\
\text { more than } 6 \text { hours }\end{array}$ & $\begin{array}{l}4.889 \\
6.286 \\
6.558 \\
6.864 \\
7.000 \\
\end{array}$ & 9.708 & 0.00000 \\
\hline & $\mathrm{S} 2$ & $\begin{array}{l}\text { less than } 1 \text { hour } \\
1-2 \text { hours } \\
\text { more than } 2-4 \text { hours } \\
\text { more than } 4-6 \text { hours } \\
\text { more than } 6 \text { hours }\end{array}$ & $\begin{array}{l}4.875 \\
6.075 \\
6.308 \\
6.682 \\
6.800 \\
\end{array}$ & 5.249 & 0.00062 \\
\hline & $\mathrm{S} 3$ & $\begin{array}{l}\text { less than } 1 \text { hour } \\
1-2 \text { hours } \\
\text { more than } 2-4 \text { hours } \\
\text { more than } 4-6 \text { hours } \\
\text { more than } 6 \text { hours }\end{array}$ & $\begin{array}{l}5.250 \\
5.750 \\
5.365 \\
6.000 \\
6.227 \\
\end{array}$ & 2.283 & 0.02805 \\
\hline \multirow{3}{*}{$\begin{array}{l}\text { The swimming competition was held over eight days. On how } \\
\text { many days did you watch live TV coverage of the swimming } \\
\text { events? }\end{array}$} & $\mathrm{S} 1$ & $\begin{array}{l}0 \\
1 \\
2 \\
3 \\
4 \\
5 \\
6 \\
7 \\
8\end{array}$ & $\begin{array}{l}4.714 \\
6.667 \\
5.938 \\
6.154 \\
6.636 \\
6.556 \\
6.667 \\
7.000 \\
6.696\end{array}$ & 5.305 & 0.00001 \\
\hline & $\mathrm{S} 2$ & $\begin{array}{l}0 \\
1 \\
2 \\
3 \\
4 \\
5 \\
6 \\
7 \\
8 \\
\end{array}$ & $\begin{array}{l}4.500 \\
6.000 \\
5.375 \\
5.769 \\
6.455 \\
6.222 \\
6.333 \\
7.000 \\
6.674 \\
\end{array}$ & 5.113 & 0.00002 \\
\hline & S3 & $\begin{array}{l}0 \\
1 \\
2 \\
3 \\
4 \\
5 \\
6 \\
7 \\
8\end{array}$ & $\begin{array}{l}4.750 \\
6.333 \\
5.500 \\
5.077 \\
5.636 \\
5.611 \\
5.667 \\
7.000 \\
5.804 \\
\end{array}$ & 1.803 & 0.04602 \\
\hline
\end{tabular}


Table 3. Factor matrix, Cronbach's $\alpha$, composite reliability, and eigenvalues by reflective variable blocks with component analysis extraction method

\begin{tabular}{|c|c|c|c|c|c|c|}
\hline Constructs & Variables & Factor 1 & $\begin{array}{c}\text { Cronbach's } \\
\boldsymbol{a} \\
\end{array}$ & $\begin{array}{c}\text { D.G. rho } \\
\text { (CR) }\end{array}$ & $\begin{array}{c}\text { Critical } \\
\text { value }\end{array}$ & Eigenvalues \\
\hline \multirow[t]{3}{*}{ Satisfaction } & S1 & 0.760 & 0.819 & 0.892 & 1 & 2.21 \\
\hline & S2 & 0.820 & & & & 0.51 \\
\hline & S3 & 0.918 & & & & 0.28 \\
\hline \multirow[t]{3}{*}{ Participation Intention } & Particip1 & 0.887 & 0.736 & 0.855 & 1 & 2.02 \\
\hline & Particip2 & 0.936 & & & & 0.82 \\
\hline & Particip3 & 0.597 & & & & 0.16 \\
\hline \multirow[t]{2}{*}{ Attendance Intention } & Att1 & 0.944 & 0.693 & 0.867 & 1 & 1.53 \\
\hline & Att2 & 0.772 & & & & 0.47 \\
\hline
\end{tabular}

a. PCA was performed on Weighted Sum Scores of the variables corresponding to each of the Involvement dimensions: Pleasure, Self-expression, and Centrality. 
Table 4. Results of the outer model: first-order latent variables with reflective indicators

\begin{tabular}{|c|c|c|c|c|c|c|c|}
\hline Latent variable & $\begin{array}{c}\text { Manifest } \\
\text { variables Label }\end{array}$ & $\begin{array}{l}\text { Standardized } \\
\text { loadings }\end{array}$ & $\begin{array}{l}\text { Standardized } \\
\text { loadings } \\
\text { (Bootstrap) }\end{array}$ & $\begin{array}{l}\text { Critical } \\
\text { ratio }(\mathrm{CR})\end{array}$ & $\begin{array}{l}\text { Lower } \\
\text { bound } \\
(95 \%)\end{array}$ & $\begin{array}{l}\text { Upper } \\
\text { bound } \\
(95 \%)\end{array}$ & $\begin{array}{c}\text { Average } \\
\text { Variance } \\
\text { Extracted } \\
\text { (AVE) }\end{array}$ \\
\hline \multirow[t]{3}{*}{ Satisfaction } & $\mathrm{S} 1$ & 0.876 & 0.871 & 27.369 & 0.804 & 0.924 & \multirow[t]{3}{*}{0.726} \\
\hline & $\mathrm{S} 2$ & 0.937 & 0.932 & 61.071 & 0.896 & 0.960 & \\
\hline & S3 & 0.730 & 0.736 & 12.374 & 0.564 & 0.863 & \\
\hline \multirow[t]{3}{*}{ Participation Intention } & Particip1 & 0.969 & 0.900 & 5.949 & 0.251 & 0.986 & \multirow[t]{3}{*}{0.636} \\
\hline & Particip2 & 0.942 & 0.854 & 5.097 & 0.195 & 0.973 & \\
\hline & Particip3 & 0.683 & 0.692 & 4.817 & 0.096 & 0.958 & \\
\hline \multirow[t]{2}{*}{ Attendance Intention } & Att1 & 0.799 & 0.792 & 22.084 & 0.716 & 0.862 & \multirow[t]{2}{*}{0.755} \\
\hline & Att2 & 0.934 & 0.932 & 52.919 & 0.883 & 0.968 & \\
\hline
\end{tabular}


Table 5. Standardized results and significance of path coefficients: pooled and group samples

\begin{tabular}{|l|c|c|c|}
\cline { 2 - 4 } \multicolumn{1}{c|}{} & $\begin{array}{c}\text { Pooled Sample } \\
\mathbf{N = 3 1 6}\end{array}$ & $\begin{array}{c}\text { On site } \\
\mathbf{N = 1 8 5}\end{array}$ & $\begin{array}{c}\text { Plymouth } \\
\mathbf{N = 1 3 1}\end{array}$ \\
\hline Satisfaction $\rightarrow$ Participation & 0.096 & $\mathbf{0 . 2 3 7}$ & $\mathbf{0 . 0 3 2}$ \\
Satisfaction $\rightarrow$ Attendance & 0.49 & 0.472 & 0.517 \\
\hline
\end{tabular}

Note: Bold values represent significant differences in path coefficients across groups. 


\section{$\underline{\text { Figure captions }}$}

Figure 1. The proposed hypothetical model of satisfaction on spectators' intentions.

Figure 2. Results of proposed model of satisfaction on participation and attendance intentions with the standardized solution for inner model from PLS-SEM using XLSTAT. 